4th International Scientific Conference SEC-IASR 2019,

Galati, Romania, 7th - 8th June, 2019

\title{
The Analysis of the Parametres of Motor Training of Senior Volleyball Players Nationally
}

\author{
Neculai HARABAGIU, Alexandru PĂCURARU \\ https://doi.org/10.18662/lumproc/sec-iasr2019/30
}

How to cite: Harabagiu, N., \& Păcuraru, A. (2020). The Analysis of the Parametres of Motor Training of Senior Volleyball Players Nationally. In S. Marin \& P. Moisescu (vol. eds.), Lumen Proceedings: Vol. 12. 4th International Scientific Conference SEC-LASR 2019 (pp. 285-293). Iasi, Romania: LUMEN Publishing House. https://doi.org/10.18662/lumproc/sec-iasr2019/30 



\title{
The Analysis of the Parametres of Motor Training of Senior Volleyball Players Nationally
}

\author{
Neculai HARABAGIU1*, Alexandru PĂCURARU²
}

\begin{abstract}
Nowadays, the volleyball game has become a very dynamic one. Its swiftness is given by the great speed of execution of the technical elements and game procedures. Therefore, the players must have an appropriate level of motor training. This thing, in particular, refers to the senior volleyball players, where the level of physical training is a determining one and it reflects in their performances within national and even international competitions. All of these make up an assessment criterion for the selection of players nationally, where the sportsmen activate both in the European competitions, as well as worldwide ones. The Romanian Federation of Volleyball places at the disposal of the participating teams in the National Championship of Romania several guiding tests, so as to highlight the level of motor training of players in all the training stages, including the competitional ones. In this context, we had the same objective in our research, where we tested the level of the motor training specific for the participating teams in the National Championship of Male Volleyball, while the collected results are to be used in an experimental study, oriented towards increasing the effort capacity of the sportsmen and implicitly, increasing the efficiency in the game of senior volleyball players by applying the "Data Volley" software of statistical assessment.
\end{abstract}

Keywords: Analysis; parameters; motor training; volleyball.

\footnotetext{
1 The State University of Physical Education and Sports from Chişinău, Moldova, E-mail address: nicu hara@yahoo.com

2 "Lower Danube” University of Galați, Galati, E-mail address: apacuraru@,ugal.ro 


\section{Introduction}

Of the four factors of sports training for all the age categories, including at the level of senior players, the motor training of sportsmen can be decisive in the fate of a game or even of a tournament. This thing is obvious also in the volleyball game for all the age categories [1], [3], [8].

In our case, when we talk about the physical training of senior volleyball players, we are interested in what their level of physical training is nationally. It is worth mentioning that at this level, there can be no talk of a significant increase of the capacity of physical training of volleyball players, but only about maintaining their staying fit and trained condition at the level of the requirements of the European volleyball [2], [7].

\section{Problem Statement}

After we reviewed the game quality level of senior volleyball players, we aimed to analyse also their level of motor training. The recorded results were compared to the national standards of the Volleyball Federation in Romania, so as to find out exactly the level of physical training of senior volleyball players enlisted in the National Championship of Volleyball [6].

\section{Research Questions/Aims of the research}

The main purpose of this study is to increase the effort capacity of the sportsmen and implicitly, to increase the efficiency in the game of Senior volleyball players, by applying "Data Volley", the programme of statistical assessment.

\section{Research Methods}

Therefore, we selected six motor tests which mostly represent the majority of the physical capacities necessary for the volleyball game at any level, including that of the senior players. These were: the speed tests (running $2 \times 10 \mathrm{~m}$ ), the test for specific agility (running between cones with a change of direction), the test of abdominal force (lifting the torso from a lying position, facing up), the Vertec test (vertical jump), the flexibility test and the force test in speed mode. These data were taken over from the teams participating in the National Championship of Male Volleyball at the level of senior players, statistically processed and showed in the following table (table1) [4], [5]. 
Neculai HARABAGIU \& ... | Lumen Proceedings 12 | SEC-IASR 2019

Table 1.Indications of the motor training of senior volleyball players nationally

\begin{tabular}{llccc}
\hline $\begin{array}{l}\text { Crt. } \\
\text { no. }\end{array}$ & \multicolumn{1}{c}{ Motor test } & $\begin{array}{l}\text { Team } \\
\text { average }\end{array}$ & $\begin{array}{l}\text { National } \\
\text { standard }\end{array}$ & Difference \\
\hline 1. & Running 2x10m, (sec) & 4.52 & 4.45 & 0.07 \\
2. & $\begin{array}{l}\text { Moving with a change } \\
\text { of direction between 5 } \\
\text { cones, (sec) }\end{array}$ & 10.83 & 10.51 & 0.32 \\
3. $\quad \begin{array}{l}\text { Lifting the torso from } \\
\text { a lying position facing } \\
\text { up, (no. of rep.) }\end{array}$ & 44.27 & 43.00 & 1.27 \\
4. & Vertical jump, (cm) & 34.15 & 35.00 & 0.85 \\
5. $\quad \begin{array}{l}\text { Bending forward from } \\
\text { a sitting position, (cm) } \\
\text { Force in speed mode } \\
\text { (the Burpee Test), (no. } \\
\text { of rep.) }\end{array}$ & 12.87 & 17.90 & 5.03 \\
\hline
\end{tabular}

Further on, we shall analyse each motor capacity specific for the volleyball game and compare it with the national standards for the senior volleyball players. Thus, the first indicator that was subjected to our research was the speed running test $2 \times 10 \mathrm{~m}$ (fig. 1.).

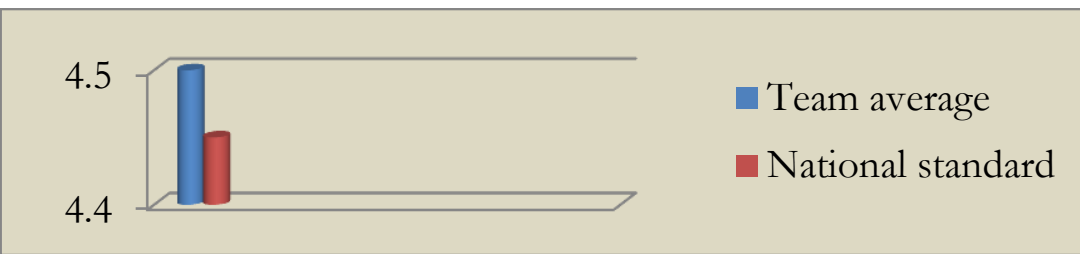

Fig. 1. The level of development of the specific speed, running $2 \times 10 \mathrm{~m}$

For the volleyball players, there are typical the running sessions for short distances with maximum speed and with a sudden change of the moving direction. In order to highlight the level of moving speed of the sportsmen, we resorted to the $2 \times 10 \mathrm{~m}$ speed test. Analysing this indicator, we notice that the volleyball players recorded a result of 4.52 seconds on average. If we were to compare it to the national scale of the Romanian 
Federation of Volleyball, we see that the average of the volleyball players within the National Championship is below this scale, being equal to 4.45 seconds. At first sight, it might seem that the difference is not very big, but 0.07 seconds for this level is a very important one. Moreover, the speed capacity is very hard to develop to great proportions and in a very short time, which is why this result of the teams within the National Championship of senior volleyball players can be considered one below average.

The following test characteristic for the volleyball game was the movement between cones (fig. 2.), in which the sportsmen had to perform a movement with maximum speed, touching each cone in part and returning to the centre after each touch, changing the moving direction.

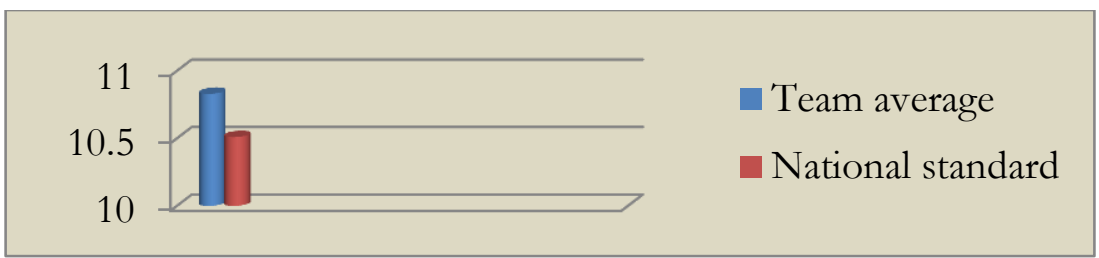

Fig. 2. The level of development of the specific movement, running between cones movement

This test, as well as the previous one, represents the specific movement speed of volleyball players on the game field depending on the situations created on field. As mentioned, this test represents the capacity of moving on field under any form so as to cope with any game situation. If we were to analyse the results recorded by the senior players within the National Championship of volleyball following this test, we would see that they registered a result equal to 10.83 seconds. At the same time, the standard of the Romanian Federation of Volleyball is of 10.51 seconds. The difference between the team averages in the National Championship and the standards of the Romanian Federation of Volleyball is of 0.32 seconds, this being actually a significant difference for such a test. Therefore, as concerns the movement on field, the players scored some rather poor results as compared to the current standards.

The following test taken by the players of the teams within the National Championship of Volleyball at the level of senior players was the test representing the abdominal force of the players (fig. 3). One should note that the abdominal force is very important for volleyball players, which is 
why the coaches place a great importance on developing and maintaining this capacity, regardless of their game position.

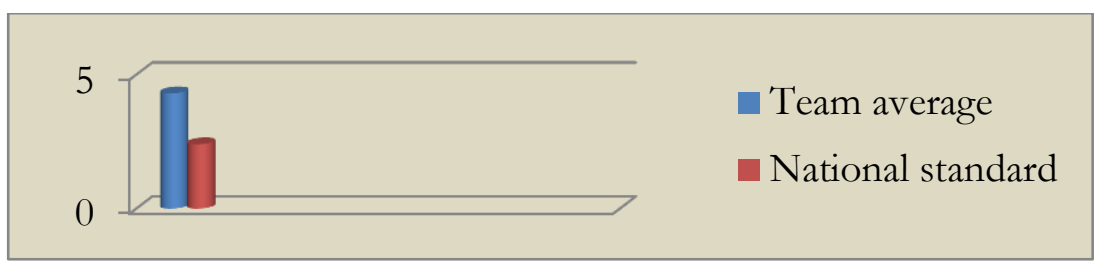

Fig. 3. The level of developing the abdominal force, lifting the torso

The test implied that the players had to accomplish the torso lifts for 30 seconds from a lying position, face up. If we were to monitor the average result registered by the teams in the National Championship of Senior Volleyball Players, we see that it is of 44.27 repetitions. The standard of the Federation in Romania is of 43 repetitions, namely that it is under the result registered by the teams in the National Championship. We have to mention the fact that force is a motor capacity, which can be fairly easily influenced and developed to the extent when it is necessary, and the better result scored by the teams in the championship stands as proof.

A test quite typical for the volleyball game is the vertical jump. For this, we opted for the Vertec test, an extremely practical test, where the sportsmen had to do a maximum jump using the stamp on both feet and the elevation of both arms, so as to reach the highest point possible of the Vertec device. (fig.4).

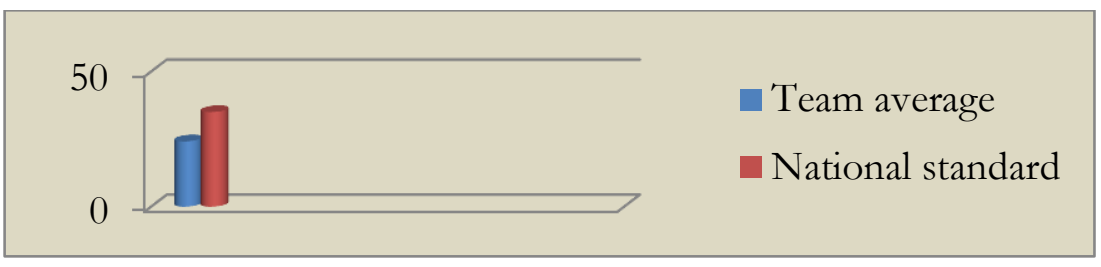

Fig. 4. The level of developing the detent, vertical jump

There are more ways to test the detent, but in the given case, it was applied a practical version and commonly seen in performance sports. If we were to analyse the results recorded by the teams participating in the National Championship of Senior Male Volleyball, we can notice that the averages in this sense are of 34.15 centimetres. The standard of the Romanian Federation of volleyball is of 35 centimetres. Actually, this indicator is the closest in value to the team averages in the National 
Championship and standards of the federation, the difference being small, of less than a centimetre.

Therefore, the majority of coaches show an increased attention to this indicator, the detent being a very important factor in the volleyball game, because except for the libero position, all the other game positions on field perform more jumps in the attack stage, then in the defence one (attack-blocking).

The following test applied within the made researches was about assessing the mobility of joints of the senior volleyball players. (fig.5)

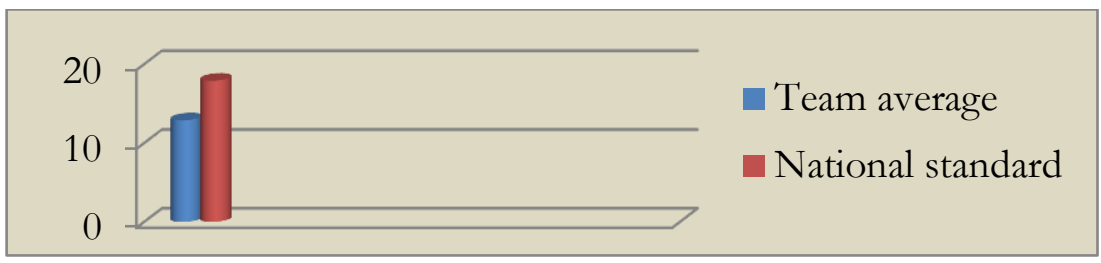

Fig. 5. The level of developing the mobility, bending forward

During the official games and not only then, volleyball players are put into difficult game situations when they have to do great efforts in order to save a ball during a game phase. Therefore, they need to have a very good mobility of the joints. In our case, the most involved joints are those of the spine and the hip joint, which is also the largest joint of the human body. In order to find out the level of development of this joint, a flexibility test was unfolded: from a sitting position, the sportsmen had to do a forward bending of the torso (knees laid down), thus it was measured the distance from the tip of the lower limbs to the tip of the upper limbs.

Analysing the recorded results, we can see that the sportsmen participating in the National Championship of Volleyball scored values of 12.56 centimetres, as compared to 16 centimetres indicated by the standard of the Federation. If we were to analyse in detail the evolution of this indicator, we notice that the average result of the teams in the National Championship is of 3.44 centimetres, this being a significant difference between the two values.

The sixth test was that of highlighting the level of force in speed mode, the control, balance and coordination of the entire body (fig. 6) 


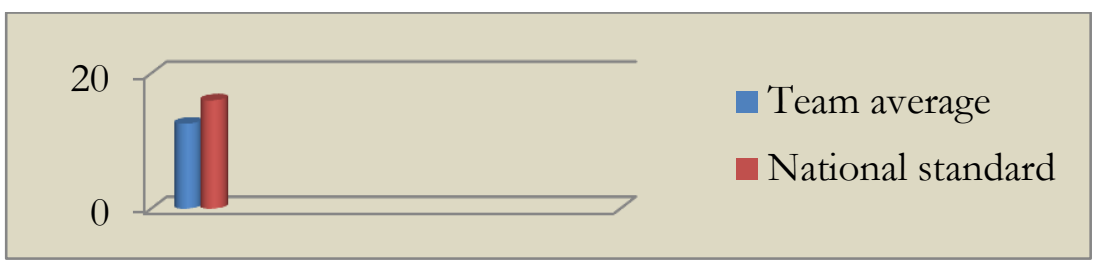

Fig. 6. The level of development of force in speed mode

In the volleyball game, the joints of the upper limbs and of the lower limbs are very strained both during practice, as well as during the official games, when the sportsmen perform a hugely large number of jumps, movements in the field, hits etc. This is why we chose a more complex exercise (the Burpee Test), which is made up of a combination of jump squats, push-ups and crunches. This test assesses the functional status of the entire body, throughout it, the sportsmen have to do several repetitions for 30 seconds.

\section{Findings}

According to the recorded results, within the National Championship of Volleyball in Romania, the sportsmen showed an average of results to this test equal to 12.56 repetitions of the given exercise. In this case, the scale of the Romanian Federation is much larger being equal to 17.90 repetitions for an excellent result. The difference between the two results is big enough, but the capacity of force in speed mode can be relatively easily improved, while the specialist can take the measures needed in this sense.

\section{Conclusions}

Thus, analysing the results of the level of motor training of volleyball players within the National Championship of Volleyball for seniors, we notice a clear tendency of the specialists to maintain the teams in a physical shape which is as good as possible to cope with the challenges and modern requirements of this game. As turns out from the recorded results within the findings experiment, one can clearly notice that the best results regarding the level of the motor capacities specific to the senior volleyball players were recorded in the case of force tests, talking about the abdominal force, the team average being over the standards of the Romanian Federation of Volleyball. 
Very close to the scales of the Romanian relevant Federation there were also the tests that relate to the sportsmen's movement in the field, the difference being of only 0.32 seconds. The biggest changes were recorded in the case of the suppleness test, this being of 5 centimetres for two measurements, and in the case of expressing the force in speed mode, it recorded an average discrepancy of 3.44 repetitions of the exercise indicated in the text.

Hence, the most difficult tests were and remain those expressing the speed of performance, factor which requires a lot of time for developing or improving it, whereas the tests that stood out were those of force and forcespeed, which can be developed relatively easier and in a much shorter time.

All these results allow us to highlight one of the reasons for which the players can commit performance mistakes of the technical elements, or even fail them completely. Following the analysis of the recorded results, the coach can come up with some solutions to optimize the level of the specific physical training of volleyball players in the training process.

\section{References}

[1] Amzar E, Macri A, Rada L. Optimization of Force Explosive Parameters Through Athletic Means Specific to Performance Volleyball Pre-competition Period]. IJNTR. April 2016; 2(4).

[2] Bompa TO. Teoria antrenamentului sportiv. Bucharest:C.C.P.S.; 2000. pp.1218,166-171.

[3] Bompa TO.Antrenamentul sportiv. Periodizarea. Bucharest: C.C.P.S.; 2002. $435 \mathrm{p}$.

[4] Bosco C. Relația forță - viteză şi performanță. Scuola dello Sport. 2. Roma [Sportul de performanță]; 1983. pp. 174-180, 237.

[5] Federation Internationale de volleyball. Coaches Manual Level I. Basic Physical Conditioning. Chapter X. 2011; pp. 136-138. Available from: http://volleyball.ir/wp-content/uploads/2017/11/1-

FIVB_DEV_Coaches_Manual_Level_I.pdf.

[6] Federation Internationale de volleyball. Coaches Manual Level II. Physical Training for Volleyball (Chapter 2). pp. 16-30. Available from: http://www.fivb.org/EN/Technical-

Coach/Document/FIVB_DEV_Coaches_Manual_Level_II.pdf.

[7] Dragnea A. Teoria şi metodica dezvoltării calităților motrice. Bucharest: The "Ministry of Youth and Sports" Publishing; 1991. pp. 58-72. 
Neculai HARABAGIU \& ... | Lumen Proceedings 12 | SEC-IASR 2019

[8] Iacob I, Păcuraru A. Volei. Dezvoltarea calităţilor motrice. Iasi: Chemarea Publishing; 1999. pp. 50-54, 75-82. 